\title{
FORENSIC IMPORTANCE OF INTRAORAL PHOTOGRAPHS FOR HUMAN IDENTIFICATION IN DENTAL AUTOPSIES: A CASE REPORT
}

\author{
IMPORTÂNCIA PERICIAL DAS FOTOGRAFIAS INTRAORAIS PARA A \\ IDENTIFICAÇÃO HUMANA EM AUTOPSIAS ODONTOLÓGICAS - RELATO DE \\ CASO
}

\begin{abstract}
Rhonan Ferreira SILVA ${ }^{1}$; Matheus FELTER ${ }^{2}$; Pedro Henrique Moreira Paulo TOLENTINO²; Michelle Gouveia Benicio de Araujo ANDRADE ${ }^{3}$; Livia Graziele RODRIGUES ${ }^{2}$; Ademir FRANCO

1. Doctor, Professor of Forensic Dentistry, School of Dentistry, Federal University of Goias, Goiania, GO, Brazil; Forensic Expert of Scientific Police, State of Goias, Goiania, GO, Brazil; 2. Post graduate student in Dentistry, Federal University of Goias, Goiania, GO, Brazil; 3. Post graduate student in Forensic Dentistry, Brazilian Association of Dentistry, Seccion of Goias, Goiania, GO, Brazil; 4. Doctor, Professor of Semiology, School of Dentistry, Federal University of Parana, Curitiba, PR, Brazil.
\end{abstract}

\begin{abstract}
Human identification may be achieved through fingerprint, teeth and DNA analyses. In these approaches, identification is given comparatively - between antemortem (AM) and postmortem (PM) data. Intraoral photographs, commonly used in Orthodontics, represent a source of dental identifiers in Forensic Dentistry. The present study aims to report a case of human identification founded on the analysis of intraoral photographs. An unknown human body was referred for cadaveric examination, which revealed all the permanent teeth fully erupted in the oral cavity. Among the distinctive dental traits, occlusal amalgam restorations were observed in the mandibular first molars, as well fixed orthodontic appliances with bands in the same teeth. Intraoral photographs were provided by the relatives of the potential victim. In these photographs, the same distinctive dental traits were observed leading to a positive identification without explainable discrepancies. The use of intraoral photographs for forensic purposes must be encouraged in medicolegal institutes because these are practical, low-cost, absent of radiation and reliable tools in the human identification process.
\end{abstract}

KEYWORDS: Forensic Dentistry. Forensic Anthropology. Dental Records. Intraoral Photographs.

\section{INTRODUCTION}

The identification of charred, mutilated and putrefied bodies (SILVA et al., 2015a; SILVA et al. 2015b; MIRANDA et al., 2016), as well skeletal remains through the analysis of dental traits figures as one of the procedures performed by forensic dentists in medico-legal institutes. The need for dental autopsies became more evident in the last years as consequence of the increase in urban violence rates (OLIVEIRA et al. 2015).

Dental autopsies for human identification are performed based mainly on the comparison of postmortem (PM) and antemortem (AM) data (ROTHWELL, 2001). While in one hand the PM data is potentially obtained through a large variety of possibilities during the cadaveric examination (FRANCISCO et al., 2016), the acquisition of AM data, on the other hand, is limited to the existing dental or social records (MIRANDA et al., 2016; SILVA et al. 2015a).

The AM data from dental records includes the registration of therapeutic procedures, intra- and extra-oral radiographs and dental casts (SILVA et al., 2011; SILVA et al., 2015c). These data are usually used for dental human identification based on their high prevalence in the clinical routine of Dentistry - especially for planning oral rehabilitations, restorations and surgeries (SILVA et al., 2011; SILVA et al. 2015a).

Intraoral photographs also appear among the AM data useful for human identification. Despite used frequently in the routine of Orthodontics, these photographs are scarce in the human identification cases reported in the scientific literature (PARANHOS et al., 2008). In comparison with other AM data, intraoral photographs have the advantage of registering morphological, therapeutic and pathological identifiers used for dental human identification without exposing the patient to radiation and the need for expensive imaging devices and facilities (SILVA et al., 2011).

In order to highlight and illustrate the forensic importance of intraoral photographs for dental human identification, the present study aims to report a case of skeletal remains positively identified based on dental traits registered in intraoral photographs taken for Orthodontic treatment purposes. 


\section{CASE REPORT}

An unknown human body was found highly decomposed in a Forest region in Central Brazil. Several body parts were skeletonized, especially the upper and lower limbs. After crime scene investigation, the body was referred to the local medico-legal institute for establishing the cause of death and performing the identification.

The cause of death was established as brain trauma and was founded on two skull fractures detected on the preliminary cadaveric examination, which involved the frontal and occipital bones and suggested wounds from a firearm projectile. The identification was hampered due to the lack of fingerprints due to the decomposition of the soft tissue. Based on that, the dental autopsy was conducted. The victim present all the permanent teeth fully erupted in the oral cavity, including the third molars. Dental age estimation was performed following the technique of NICODEMO, MORAES, MEDICI FILHO (1974) and indicated age above 20.5 years. In both dental arches fixed orthodontic appliances were observed from right to left first molars, which also presented orthodontic bands. Occlusal amalgam restorations were detected in the mandibular right and left first molars. Premolars were rotated discretely and diastemas were observed in the anterior region of the maxilla (Figure 1).

In parallel to the forensic expertises, police investigations pointed to a potential victim aged 32 years old missing for 20 days. Relatives of the potential victim were asked to provide any source of evidences that could support the investigations. Orthodontic records were provided, including intraoral photographs and a panoramic radiograph dating 7 months before the body was found. The same dental traits observed PM were detected in the AM data, such as the quantity of teeth present, the amalgam restorations, the rotation, the diastema and the fixed orthodontic appliances (Figure 2).

It is important to note that devices and facilities for the PM radiographic examination were temporarily unavailable in the local medico-legal institute. Radiographic exams could be performed in private clinics. However, performing such exams out of the forensic services would delay the identification process and increase the respective costs. Based on that, the positive human identification was founded on the comparison of photographic dental data (Figure 3). This decision was taken especially because the identifiers detected in the photographic records were distinctive enough to support the case. Discrepancies (explainable or not) were not observed between AM and PM data.
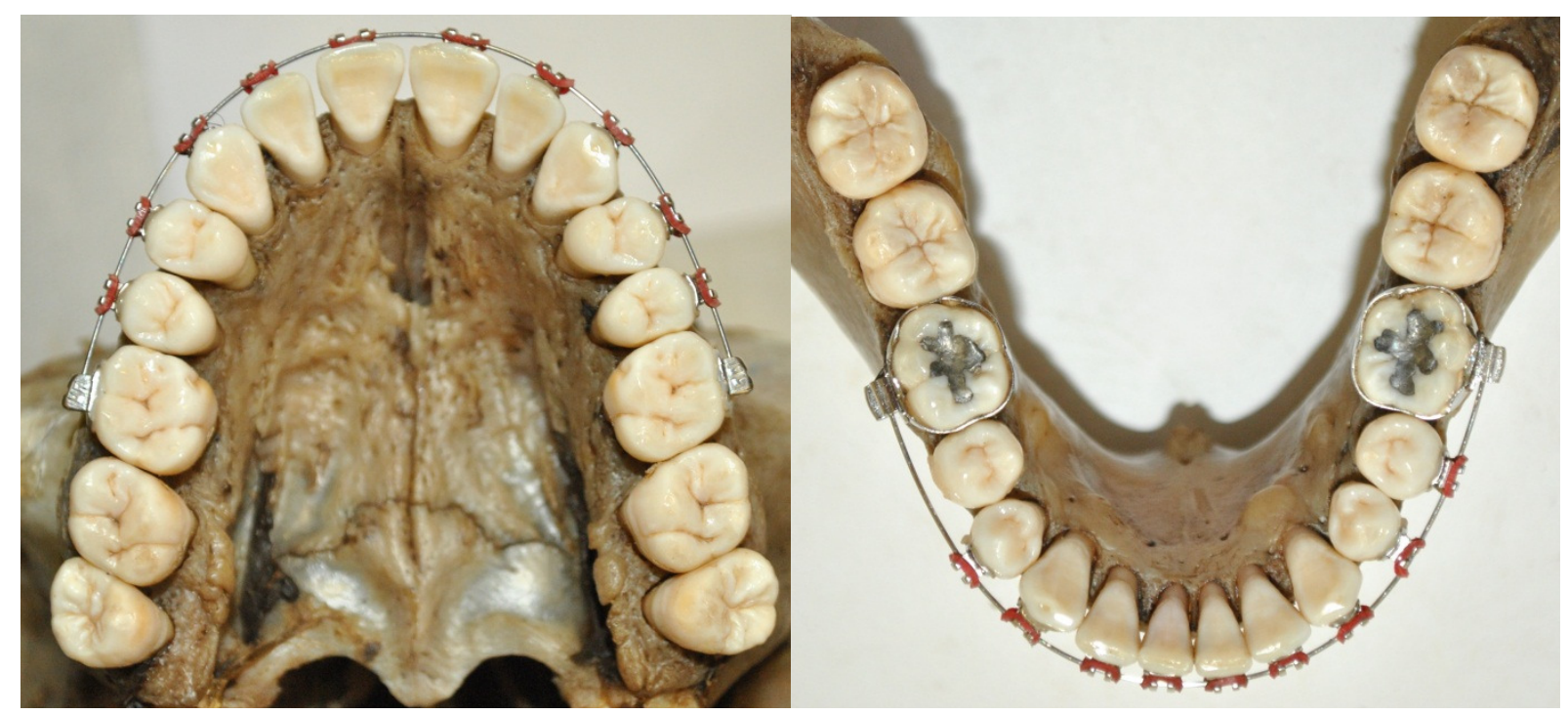

Figure 1. Postmortem (PM) occlusal view of the maxilla and mandible. 

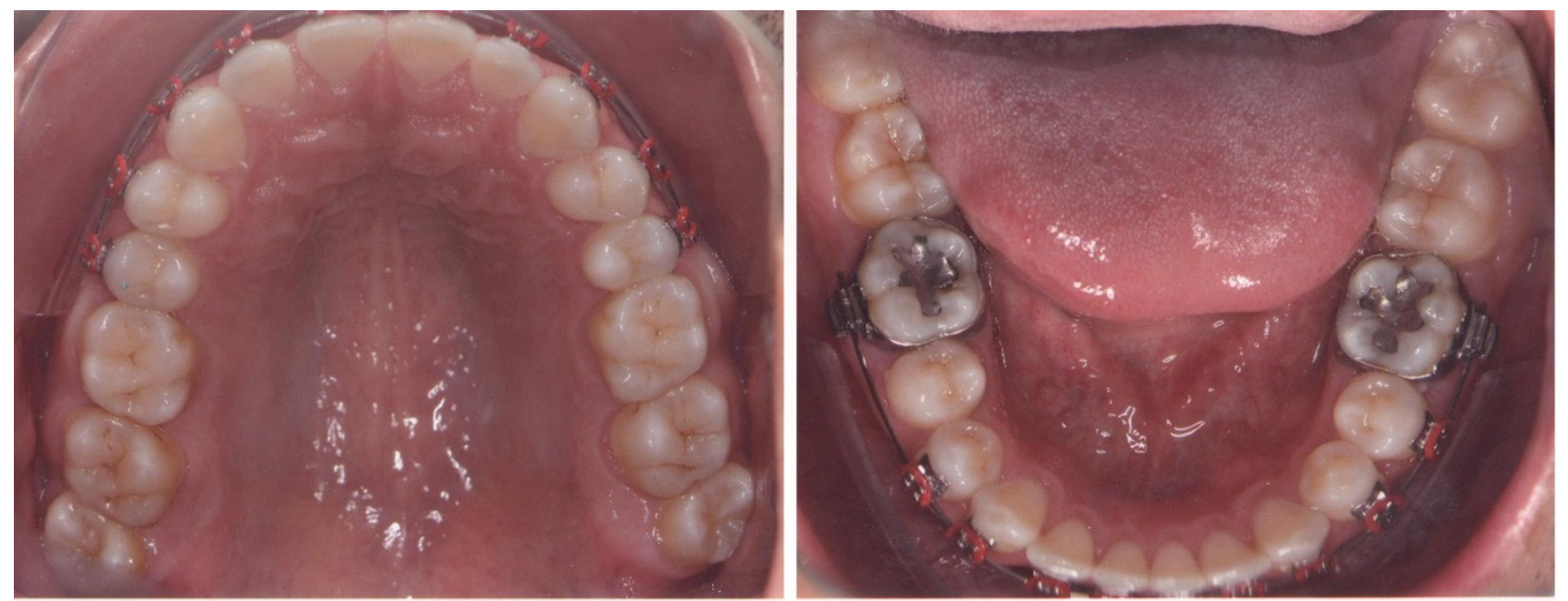

Figure 2. Occlusal view of the upper and lower arches antemortem (AM).

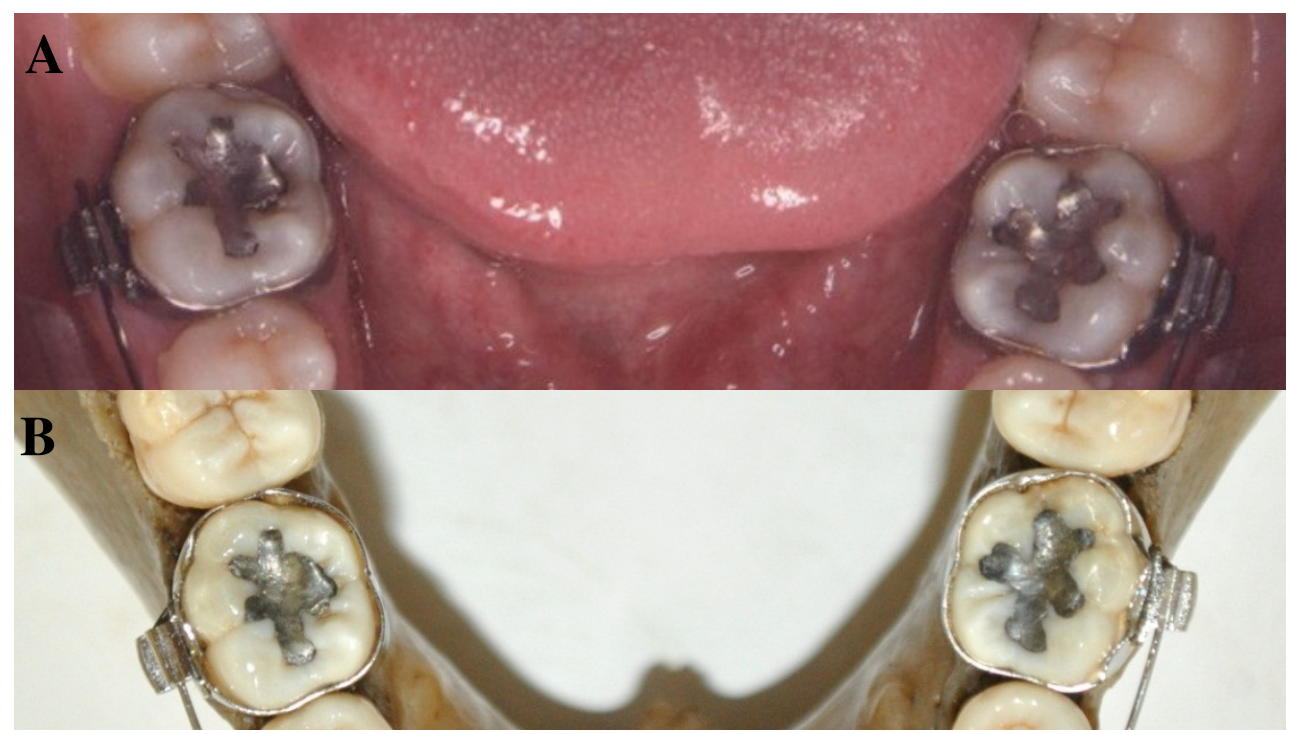

Figure 3. Photographic matching of the amalgam restorations observed in the lower first molars antemortem (A) and postmortem (B).

\section{DISCUSSION}

Forensic Dentistry has proven for many time its value for human identification in Forensic Sciences (MIRANDA et al., 2016; SILVA et al., 2015a; SILVA et al. 2015b). According to the scientific literature, the victims referred for identification by dental means come from different types of incidents, such as natural disasters, flight accidents, terrorist attacks and urban violence (MIRANDA et al., 2016; SILVA et al., 2011; SILVA et al., 2015a; SILVA et al. 2015b). The advantage of teeth as source of identifiers relies also in their capacity to resist environmental influences. Consequently, morphological, therapeutic, anthropological and pathological identifiers may be found in teeth even after postmortem body alterations (e.g. decomposition and carbonization) (MIRANDA et al., 2016; SHIMADA et al. 2016; SILVA et al., 2011).

Once examined PM, the human teeth must be compared with AM data. In fact, the success of dental human identification depends strongly on the AM data available (ROTHWELL, 2001). Clinical files with the registration of therapeutic procedures are the most prevalent data available for human identification. The high prevalence of these data is justified on the need for registering constantly treatment steps and follow up clinically. However, orthodontic records became more prevalent over the last years in the routine of dental human identification due to the popularization and accessibility to orthodontics treatment. As consequence, the intraoral photographs used to 
register therapeutics before, during and after the orthodontic treatment became more often part of the AM data available in Forensic Dentistry (PARANHOS et al., 2008; SILVA et al., 2011; TERADA et al., 2014).

In the present study the case reported was founded on orthodontic records produced during the treatment, which enabled the analysis of the permanent teeth through intraoral photographs and a panoramic radiograph. In many medico-legal institutes of developing countries radiographic exams are not feasible. The present case was not different. Fortunately, distinctive dental identifiers were observed both PM and AM - in the cadaver and in the orthodontic photographs, respectively. From the scope of forensic practice, intraoral photographs have advantages over radiographs, which include the lack of radiation, lower cost and less time spent for image acquisition.

Considering the reliability of dental human identification, INTERPOL (2014) classifies fingerprint, Forensic Dentistry and Genetics as primary scientific means to identify victims of mass disasters. In specific, Forensic Dentistry allows the qualitative and quantitative analysis of dental identifiers and contributes to support positive identifications even with a single concordance between AM and PM data. However, it is important to note that despite offering a reliable, quick, lowcost and accurate identification, dental human identification requires trained and qualified professionals for optimal outcomes in the routine of medico-legal institutes (SILVA et al., 2011; SILVA et al., 2015a).

\section{CONCLUSION}

Intraoral photographs represent a reliable tool for dental human identification. As illustrated in the present case, these photographs consist of source of dental information that may lead to a positive identification with no discrepancies between AM and PM data. Additionally, intraoral photographs are standardly required for orthodontic treatment and may be available more often for human identifications with the popularization of Orthodontics. With low-cost devices, quick procedures and using no radiation, intraoral photographs represent a valuable tool in Forensic Dentistry and must be encouraged to support human identification cases.

RESUMO: O processo de identificação humana pode se dar cientificamente confiável por meio dos exames da papiloscopia, odontologia e genética. Nestas três vertentes, a identificação comparativa - entre dados antemortem (AM) e postmortem $(\mathrm{PM})$. As fotografias intrabucais, comumente utilizadas em Ortodontia, representam fonte de caracteres identificadores em Odontologia Legal. O presente estudo objetiva relatar um caso pericial fundamentado na utilização de fotografias intrabucais para a identificação humana. Um corpo não identificado foi encaminhado para exame necroscópico revelando a presença de todos os dentes permanentes completamente erupcionados na cavidade bucal. Dentre os caracteres dentais distintivos observados na vítima, encontravam-se restaurações oclusais de amálgama nos primeiros molares inferiores, assim como aparelho ortodôntico fixo ancorados por bandas nestes mesmos dentes. Fotografias intrabucais provenientes de tratamento ortodôntico foram fornecidas pelos familiares da suposta vítima. Nestas, os mesmo caracteres distintivos foram detectados gerando identificação positiva sem discrepâncias inexplicáveis. A utilização de fotografias intrabucais com finalidade forense deve ser divulgada e encorajada em institutos médico-legais, uma vez que representa meio prático, de baixo custo, isento de radiação e confiável para o processo de identificação humana. Intrabucal.

PALAVRAS-CHAVE: Odontologia Legal. Antropologia Forense. Registros Odontológicos. Fotografia

\section{REFERENCES}

FRANCISCO, R. A.; VILLALOBOS, M. I. O. B.; ORTIZ, A. G.; BIAZEVIC, M. G. H.; GUIMARÃES, M. A.; SILVA, R. H. A. The use of human teeth in identification: epidemiological data from an anthropology lab in Brazil. Biosci. J. Uberlândia, v. 32, n. 2, p. 560-565, Mar./Apr. 2016. http://dx.doi.org/10.14393/BJv32n2a2016-30195.

INTERPOL - Disaster Victim Identification Guide. 2014. Available from https://www.interpol.int/Media/Files/INTERPOL-Expertise/DVI/DVI-Guide-new-version-2013. Access in: March 22nd 2017. 
MIRANDA, G. E.; FREITAS, S. G.; MAIA, L. V.; MELANI, R. F. An unusual method of forensic human identification: use of selfie photographs. Forensic Sci. Int., New York, v. 263, n. 6, p. e14-e17, Jun. 2016. http://dx.doi.org/10.1016/j.forsciint.2016.04.028.

NICODEMO, R. A.; MORAIS, L. C.; MEDICI FILHO, E. Tabela cronológica da mineralização dos dentes permanentes entre brasileiros. Rev. Fac. Odont. São José dos Campos. São José dos Campos, v. 3, n.1, p. 55 56, 1974.

OLIVEIRA, M. C. A.; VIEIRA, E. L. R.; PENHA, M. R. C.; MELO, E. H.; CALDAS JUNIOR, A. F. Characterization of women victims of violent death in a metropolitan area of Northeast Brazil. RGO, Rev. Gaúch. Odontol. Campinas, v. 63, n. 4, p. 439-445, 2015. http://dx.doi.org/10.1590/1981863720150003000102883.

PARANHOS, L. R.; CALDAS, J. C. F.; IWASHITA, A. R.; SCANAVINI, M. A.; DARUGE JR, E. The importance of orthodontic records in forensic human identification. Ortodontia SPO. São Paulo, v. 41 (ed.espec.), n. 5, p. 297-301. 2008.

ROTHWELL, B. R. Principles of dental identification. Dent. Clin. North Am. New York, v. 45, n. 2, p. 253270, Apr. 2001.

SHIMADA, S. S.; SILVA, E. C.; RODRIGUES, L. G.; SILVA, R. F.; TORRES, E. M.; SHIMADA, R. T. Odontometric analysis of permanent canines in a brazilian population for the investigation of sexual dimorphism. Biosci. J., Uberlândia, v. 32, n. 5, p. 1422-1427, Sept./Oct. 2016. http://dx.doi.org/10.14393/BJv32n1a2016-34200.

SILVA, R. F.; CHAVES, P.; PARANHOS, L. R.; LENZA, M. A.; DARUGE JÚNIOR, E. Use of orthodontic records in human identification. Dental Press J. Orthod. Maringá, v. 16, n. 2, p. 52-57, Mar-Apr. 2011. http://dx.doi.org/10.1590/S2176-94512011000200007.

SILVA, R. F.; DIAS, P. E. M.; PICOLI, F. F.; RODRIGUES, L. G.; MUNDIM, M. B. V.; FRANCO, A. Inconsistências antropológicas observadas em corpo putrefeito identificado por registros odontológicos - relato de caso pericial. RBOL, Rev. Bras. Odontol. Leg., Ribeirão Preto, v. 2, n. 1, p. 125-136, 2015a. http://dx.doi.org/10.21117/rbol.v2i1.25.

SILVA, R. F.; FRANCO, A.; SOUZA, J. B.; PICOLI, F. F.; MENDES, S. D. S. C. Human identification through the analysis of smile photographs. Am. J. Forensic Med. Pathol., New York, v. 36, n. 2, p. 71-74, June 2015b. http://dx.doi.org/10.1097/PAF.0000000000000148.

SILVA, R. F.; MUNDIM, M. B. V.; PICOLI, F. F.; FRANCO, A. Dental identification of mummified body using dental cast and prosthesis. J. Forensic Investigation, Northborough, v.3, n. 2, n. 1-3, 2015c. http://dx.doi.org/10.13188/2330-0396.1000024.

TERADA, A. S. S. D.; ARAUJO, L. G.; PARANHOS, L. R.; SILVEIRA, T. C. P.; GUIMARÃES, M. A.; SILVA, R. H. A. Orthodontic use of documentation in identification of a skeletonized body in legal dental practice. Int. J. Odontostomat., Temuco, v. 8, n. 1, p. 41-46, 2014. http://dx.doi.org/10.4067/S0718381X2014000100004. 